\title{
Comparative efficacy of few disinfectants against bacterial load in pig facilities at livestock farm complex, Chennai
}

\section{Divyalakshmi*}

Department of Livestock Production Management, Madras Veterinary College, Chennai600007 (Tamil Nadu), India

\section{N. Kumaravelu}

Department of Livestock Production Management, Madras Veterinary College, Chennai600007 (Tamil Nadu), India

\section{B.Samuel Masilamoni Ronald}

Department of Veterinary Microbiology, Madras Veterinary College, Chennai-600007 (Tamil Nadu), India

Thanga.Thamil Vanan

Department of Livestock Production Management, Madras Veterinary College, Chennai600007 (Tamil Nadu), India

P. Tensingh Gnanaraj

Tamil Nadu Veterinary and Animal Sciences, MMC, Chennai-600051(Tamil Nadu), India

*Corresponding author. E-mail: nandhi7121989@gmail.com

\begin{abstract}
Disinfection of animal shed means making them free from disease producing organisms. An attempt has been made to assess the efficacy of disinfectants. The study was carried out in three different seasons of the year during 2017-18 in pig fattener facilities and farrowing pen at Livestock Farm Complex, Madhavaram, Chennai. Four disinfectants namely, chlorine dioxide, sodium hypochlorite, calcium hypochlorite and cow urine based disinfectant were used. The efficacy of the disinfectants was found out by dilution method. In pig fattener sty the efficacy of disinfectants in descending order were chlorine dioxide $\left(1.77 \times 10^{8} \pm 1.10\right)$, sodium hypochlorite $\left(2.57 \times 10^{11} \pm 1.15\right)$, cow urine based disinfectant $\left(1.68 \times 10^{11} \pm 1.12\right)$ and calcium hypochlorite $\left(7.73 \times 10^{11} \pm 1.06\right)$ in all the seasons of the year In farrowing pen the order of efficacy of disinfectants were chlorine dioxide $\left(1.82 \times 10^{8} \pm 1.17\right)$, sodium hypochlorite $\left(2.71 \times 10^{11} \pm 1.15\right)$, calcium hypochlorite $\left(2.66 \times 10^{11} \pm 1.17\right)$ and cow urine based disinfectant $\left(3.15 \times 10^{11} \pm 1.07\right)$ in all the seasons of the year. Hence, spraying with chlorine dioxide in pig facilities was found to be effective in all seasons of the year.
\end{abstract}

Keywords: Disinfectants, Farrowing pen, Pig fattener sty, Seasons

\section{Article Info}

https://doi.org/10.31018/ jans.vi.2248

Received: April 2, 2020

Revised: April 17, 2020

Accepted: May 3, 2020

\section{How to Cite}

Divyalakshmi, D. et al. (2020). Comparative efficacy of few disinfectants against bacterial load in pig facilities at livestock farm complex, Chennai. Journal of Applied and Natural Science, 12(2): $79-83$ https://doi.org/10.31018/ jans.vi.2248

\section{INTRODUCTION}

Intensive livestock farming provides optimum conditions for the concentration of pathogens and transmission. The crowding of animals in an enclosed environment is highly conducive for the transmission of diseases. Disinfection is one of the important activities in a commercial livestock farm to sustain the health of animals and quality of products obtained. Disinfection is a recommended disease-preventing measure that is commonly used in animal facilities. Chemical disinfectants (benzalkonium chloride, formaldehyde and glutaraldehyde) are widely used as a preventative or precautionary measure against bacterial infections in livestock animals such as cattle, swine and poultry (Lewis and Mclndoe, 2004).
However, potentially toxic, corrosive or volatile problems have arisen because of the use of chemicals as disinfecting agents. The main goal of disinfection activities is to interrupt the route of transmission of germs between the infection source and healthy subjects (Graslund and Bengtsson, 2001). Little is known about the effectiveness of cleaning and disinfection procedures applied on livestock housing in our country. The purpose of this study is to consider the hygiene systems used with pig rearing and to provide a programme of cleaning and to evolve a standard disinfection protocol. Therefore, comparative efficacy of few disinfectants was investigated against bacterial load in pig facilities at Livestock farm complex, Chennai. 


\section{MATERIALS AND METHODS}

The experiment was carried out at Livestock Farm Complex, Madhavaram, Chennai. The laboratory works were carried out in the Vaccine Research Centre - Bacterial Vaccines, Tamil Nadu Veterinary and Animal Sciences University. The experiment period comprised rainy (August - December), winter (January- February) and summer (March - April) seasons during 2017-18. Pig sty with four pens having conventional open run and pen system housing $10-13$ piglets from the age of weaning till market age. Four conventional farrowing pens that housed one sow and $10-15$ piglets in each pen were selected. The water used for mixing the disinfectants was tested for physical, chemical and microbial qualities (Table 1).

Concentration of disinfectants: The disinfectants viz., chlorine dioxide, sodium hypochlorite, calcium hypochlorite and a cow urine based mixture were tested for their efficacy as disinfectant in swine facilities. Stock solution of chlorine dioxide was prepared by adding $40 \mathrm{gm}$ of sodium chlorite in $50 \mathrm{gm}$ of citric acid reagent which was already diluted in $50 \mathrm{ml}$ water. After 30 minutes, $5 \mathrm{ml}$ of the stock solution was diluted in one litre of water and sprayed over the livestock premises. Sodium hypochlorite $4 \%$ was diluted with water and the concentration was brought down to $2 \%$ and splashed. Calcium hypochlorite $30 \%$ as readymade chemical was dusted. Cow urine based disinfectant equal quantities of the following ingredients viz., cow urine collected from indigenous cattle, freshly ground neem leaves (Azadirachta indica), tulsi leaves (Ocimum tenuiflorum) and ritha nuts (Sapindus mukorosse) were mixed along with commercially available pine oil (Pinus palustris). The mixture was prepared and sprinkled directly and mopped in the floor of livestock shed as suggested by Mandavgane et al. (2005).

Assessment of efficacy of disinfectants: To study the efficacy of the disinfectants, the microbial load in the floor of animal sheds, before and after water wash was taken in the animal sheds. The disinfectants were applied according to the recommended procedures mentioned by Prasad (1999). After application, floor swabs were taken after 1 hour, 8 hours and 24 hours post disinfection. The samples were taken in three different places (feeding area, standing area and dunging area) inside the shed with individual sterile cotton tipped swabs by swabbing within $10 \mathrm{~cm}^{2}$ area as suggested by Gibson et al. (1999). The sample was transported aseptically from sampling site to the laboratory within one hour and the test was carried on. The efficacy study of the disinfectants was carried out by dilution method where serial dilutions were done. An aliquot of $1 \mathrm{ml}$ was taken from dilution and poured in sterile petri plates in triplicate and mixed with $20 \mathrm{ml}$ of liquefied steri- lized plate count agar (Hi-Media) with a composition of Tryptone- $5.0 \mathrm{~g} / \mathrm{lt}$, Yeast extract $-2.500 \mathrm{~g} / \mathrm{tt}$, Dextrose-1.00 g/lt, Agar-15.00 g/lt having pH-7.0 \pm 0.2. After solidification of agar, the plates were incubated in inverted position at $37^{\circ} \mathrm{C}$ for 24 hours. After incubation, bacterial cells grew into distinct colonies, which were counted as CFU/ml with colony counter. All the procedures were done in Laminar air flow cabinet.

\section{RESULTS AND DISCUSSION}

Effect of chlorine dioxide in pig fattener sty and farrowing pen during different seasons against floor microbial load in pig fattener sty and farrowing pen during rainy, winter and summer is provided in Table 2. It is evident, that there was no significant difference $(\mathrm{P}<0.05)$ in the efficacy of chlorine dioxide in pig fattener sty between seasons, but highly significant $(P<0.01)$ reduction in floor microbial load was observed in post disinfection assessment in all seasons. It was noted that in farrowing pen, the floor microbial load did not differ statistically before water wash in the morning. After the application of chlorine dioxide, the reduction in microbial load did not differ significantly between seasons in one hour and eight-hour post disinfection. Highly significant $(P<0.01)$ reduction in microbial load was observed after chlorine dioxide application in all the seasons. The disinfectant effect of chlorine dioxide was reported by earlier workers in poultry and pig facilities (Luyckx et al.,

Table 1. Quality of water samples used with disinfectants.

\begin{tabular}{ll}
\hline Physical examination & \\
\hline Appearance & Clear \\
Turbidity & Nil \\
Smell & Nil \\
\hline Chemical examination & \\
\hline Parameters & Value \\
\hline Ammonia & Absent \\
Chloride & $150 \mathrm{ppm}$ \\
Sulphate & + \\
Sulphide & Absent \\
Nitrate & $+20 \mathrm{mg} / \mathrm{L}$ \\
Nitrite & $0.2 \mathrm{mg} / \mathrm{L}$ \\
Phosphate & Absent \\
Fluoride & Absent \\
Residual chlorine & Absent \\
Iron & $0 \mathrm{mg} / \mathrm{L}$ \\
Copper & Absent \\
Lead & Absent \\
Zinc & Absent \\
$\mathrm{p}^{H}$ & 6.8 \\
Alkalinity & $100 \mathrm{ppm}$ \\
Hardness & $120 \mathrm{ppm}$ \\
TDS & $510 \mathrm{ppm}$ \\
\hline Microbiological examination of water \\
\hline Total Viable Count/ml & $1.2 \times 10^{1} / \mathrm{ml}$ \\
E.coli & not detected \\
\hline
\end{tabular}


Divyalakshmi, D. et al. / J. Appl. \& Nat. Sci. 12(2): 79 - 83 (2020)

Table 2. Effect of chlorine dioxide on bacterial load of pig facilities at Livestock Farm Complex.

\begin{tabular}{|c|c|c|c|c|}
\hline \multirow{2}{*}{ Treatment } & & \multicolumn{3}{|c|}{ Bacterial load CFU/ml } \\
\hline & & Rain & Winter & Summer \\
\hline Before & Pig fattener & $1.08 \times 10^{12 \mathrm{Db}} \pm 1.24$ & $1.21 \times 10^{12 \mathrm{Db}} \pm 1.19$ & $6.21 \times 10^{11 \mathrm{Da}} \pm 1.11$ \\
\hline wash & Farrowing & $1.23 \times 10^{12 \mathrm{D}_{ \pm}}{ } .21$ & $9.38 \times 10^{11 D_{ \pm 1.28}}$ & $7.92 \times 10^{11 \mathrm{D}_{ \pm 1} .11}$ \\
\hline After & Pig fattener & $5.86 \times 10^{11 \mathrm{Cb}} \pm 1.09$ & $5.89 \times 10^{11 \mathrm{Cb}} \pm 1.19$ & $3.53 \times 10^{11 \mathrm{Ca}} \pm 1.07$ \\
\hline wash & Farrowing & $7.31 \times 10^{11 \mathrm{Cb}} \pm 1.05$ & $4.31 \times 10^{11 C a} \pm 1.20$ & $3.58 \times 10^{11 C a} \pm 1.12$ \\
\hline $1 \mathrm{hr} P \mathrm{P}$ & Pig fattener & $2.72 \times 10^{6 \mathrm{~A}} \pm 1.37$ & $1.83 \times 10^{6 \mathrm{~A}} \pm 1.30$ & $1.83 \times 10^{6 \mathrm{~A}} \pm 1.30$ \\
\hline $1 \mathrm{nr} P \mathrm{D}$ & Farrowing & $1.6 \times 10^{6 \mathrm{~A}} \pm 1.15$ & $1.86 \times 10^{6 \mathrm{~A}} \pm 1.04$ & $2.34 \times 10^{6 \mathrm{~A}} \pm 1.33$ \\
\hline $8 \mathrm{hr} P \mathrm{P}$ & Pig fattener & $1.77 \times 10^{8 \mathrm{~B}} \pm 1.10$ & $1.70 \times 10^{8 \mathrm{~B}} \pm 1.31$ & $2.27 \times 10^{8 \mathrm{~B}} \pm 1.33$ \\
\hline O & Farrowing & $1.82 \times 10^{8 \mathrm{~B}} \pm 1.17$ & $1.94 \times 10^{8 \mathrm{~B}} \pm 1.12$ & $1.72 \times 10^{8 \mathrm{~B}} \pm 1.13$ \\
\hline & Pig fattener & $1.12 \times 10^{12} \mathrm{D}_{ \pm 1} .19$ & $1.12 \times 10^{12 D_{ \pm}} 1.14$ & $7.38 \times 10^{11 \mathrm{D}_{ \pm 1} .11}$ \\
\hline $24 \mathrm{hr}$ PD & Farrowing & $1.01 \times 10^{12} \mathrm{D}_{ \pm 1.08}$ & $1.06 \times 10^{12 D_{ \pm}} \pm .18$ & $7.54 \times 10^{11 \mathrm{D}_{ \pm 1} .08}$ \\
\hline
\end{tabular}

PD: Post Disinfection; Means bearing different superscript in the same row and column differ significantly

Table 3. Effect of sodium hypochlorite on bacterial load of pig facilities at Livestock Farm Complex.

\begin{tabular}{|c|c|c|c|c|}
\hline \multirow{2}{*}{ Treatment } & & \multicolumn{3}{|c|}{ Bacterial load CFU/ml } \\
\hline & & Rain & Winter & Summer \\
\hline Before & Pig fattener & $1.17 \times 10^{12 \mathrm{Db}} \pm 1.15$ & $7.92 \times 10^{11 \mathrm{Ca}} \pm 1.11$ & $6.45 \times 10^{11 \mathrm{Da}} \pm 1.09$ \\
\hline wash & Farrowing & $9.71 \times 10^{11 \mathrm{Db}} \pm 1.07$ & $1.68 \times 10^{12 \mathrm{Dc}} \pm 1.20$ & $4.12 \times 10^{11} \mathrm{a}_{ \pm} .111$ \\
\hline After & Pig fattener & $6.28 \times 10^{11 \mathrm{Cb}} \pm 1.14$ & $3.58 \times 10^{11 \mathrm{Ba}} \pm 1.12$ & $3.23 \times 10^{11 \mathrm{Ca}} \pm 1.11$ \\
\hline wash & Farrowing & $5.17 \times 10^{11 \mathrm{Cb}} \pm 1.08$ & $6.87 \times 10^{11 \mathrm{BCb}} \pm 1.09$ & $1.85 \times 10^{11} \mathrm{a}_{ \pm 1} .37$ \\
\hline & Pig fattener & $4.26 \times 10^{11 \mathrm{Bb}} \pm 1.41$ & $3.18 \times 10^{11 \mathrm{Bb}} \pm 1.12$ & $1.57 \times 10^{11 \mathrm{Ba}} \pm 1.13$ \\
\hline 1 hr PD & Farrowing & $3.67 \times 10^{11 \mathrm{~B}} \pm 1.12$ & $5.12 \times 10^{11 \mathrm{~B}} \pm 1.18$ & $3.16 \times 10^{10} \pm 31.68$ \\
\hline & Pig fattener & $2.57 \times 10^{11 \mathrm{Ab}} \pm 1.15$ & $1.72 \times 10^{11 \mathrm{Ab}} \pm 1.13$ & $8.54 \times 10^{10 \mathrm{~A} a} \pm 1.26$ \\
\hline $8 \mathrm{hr}$ PD & Farrowing & $2.71 \times 10^{11 \mathrm{~A}} \pm 1.15$ & $2.82 \times 10^{11 \mathrm{~A}} \pm 1.17$ & $1.82 \times 10^{11} \pm 1.15$ \\
\hline & Pig fattener & $8.38 \times 10^{11} C_{ \pm 1} .05$ & $7.54 \times 10^{11 C} \pm 1.08$ & $6.6 \times 10^{11 \mathrm{D}} \pm 1.10$ \\
\hline 24 hr PD & Farrowing & $1.08 \times 10^{12 \mathrm{D}} \pm 1.03$ & $1.12 \times 10^{12 \mathrm{CD}} \pm 1.24$ & $7.67 \times 10^{11} \pm 1.09$ \\
\hline
\end{tabular}

PD: Post Disinfection; Means bearing different superscript in the same row and column differ significantly

Table 4. Effect of calcium hypochlorite on bacterial load of pig facilities at Livestock Farm. Complex.

\begin{tabular}{|c|c|c|c|c|}
\hline \multirow{2}{*}{ Treatment } & & \multicolumn{3}{|c|}{ Bacterial load CFU/ml } \\
\hline & & Rain & Winter & Summer \\
\hline \multirow{4}{*}{$\begin{array}{l}\text { Before } \\
\text { wash } \\
\text { After } \\
\text { wash }\end{array}$} & Pig fattener & $1.36 \times 10^{12 B d} \pm 1.07$ & $1.46 \times 10^{12 \mathrm{Cb}} \pm 1.16$ & $7.25 \times 10^{11 \mathrm{Da}} \pm 1.07$ \\
\hline & Farrowing & $1.61 \times 10^{12 \mathrm{Db}} \pm 1.41$ & $1.69 \times 10^{12 \mathrm{cb}} \pm 1.16$ & $5.87 \times 10^{11 \mathrm{Da}} \pm 1.10$ \\
\hline & Pig fattener & $2.51 \times 10^{11 \mathrm{Ba}} \pm 1.15$ & $7.69 \times 10^{11 \mathrm{Bb}} \pm 1.06$ & $3.5 \times 10^{11 \mathrm{Ca}} \pm 1.14$ \\
\hline & Farrowing & $5.17 \times 10^{11 \mathrm{Bb}} \pm 1.08$ & $7.83 \times 10^{11 \mathrm{~B} c} \pm 1.08$ & $3.47 \times 10^{11 \mathrm{Ca}} \pm 1.51$ \\
\hline \multirow{2}{*}{1 hr PD } & Pig fattener & $1.69 \times 10^{11 \mathrm{Aa}} \pm 1.12$ & $5 \times 10^{11 \mathrm{Ab}} \pm 1.17$ & $1.62 \times 10^{11 \mathrm{Ba}} \pm 1.11$ \\
\hline & Farrowing & $3.87 \times 10^{11 \mathrm{AB}} \pm 1.14$ & $6.80 \times 10^{11 \mathrm{BC}} \pm 1.08$ & $1.62 \times 10^{11 \mathrm{Ba}_{ \pm}} \pm 1.25$ \\
\hline \multirow{2}{*}{8 hr PD } & Pig fattener & $7.73 \times 10^{11 C c} \pm 1.06$ & $3.16 \times 10^{11 \mathrm{Ab}} \pm 1.17$ & $8.83 \times 10^{10 \mathrm{Aa}} \pm 1.22$ \\
\hline & Farrowing & $2.66 \times 10^{11 \mathrm{Ab}} \pm 1.17$ & $3.69 \times 10^{11 \mathrm{Ab}} \pm 1.16$ & $7.9 \times 10^{10 \mathrm{Aa}} \pm 1.06$ \\
\hline \multirow{2}{*}{$24 \mathrm{hr}$ PD } & Pig fattener & $1.08 \times 10^{12 \mathrm{Db}} \pm 1.05$ & $1.13 \times 10^{12 \mathrm{BCb}} \pm 1.24$ & $5.82 \times 10^{11 \mathrm{Da}} \pm 1.09$ \\
\hline & Farrowing & $9.12 \times 10^{11 \mathrm{Ca}} \pm 1.05$ & $9.51 \times 10^{11 \mathrm{Ba}} \pm 1.47$ & $7.45 \times 10^{11 \mathrm{Da}} \pm 1.06$ \\
\hline
\end{tabular}

PD: Post Disinfection; Means bearing different superscript in the same row and column differ significantly

Table 5. Effect of cow urine based disinfectant on bacterial load of pig facilities at Livestock Farm Complex.

\begin{tabular}{|c|c|c|c|c|}
\hline \multirow{2}{*}{ Treatment } & & \multicolumn{3}{|c|}{ Bacterial load CFU/ml } \\
\hline & & Rain & Winter & Summer \\
\hline \multirow{2}{*}{$\begin{array}{l}\text { Before } \\
\text { wash }\end{array}$} & Pig fattener & $9.3 \times 10^{11 C} \pm 1.17$ & $8.09 \times 10^{11} \mathrm{C}_{ \pm 1.05}$ & $8.2 \times 10^{11 \mathrm{D}} \pm 1.10$ \\
\hline & Farrowing & $1.74 \times 10^{12 \mathrm{Db}} \pm 1.37$ & $2.91 \times 10^{12 \mathrm{Cb}} \pm 1.45$ & $6.17 \times 10^{11 C a} \pm 1.13$ \\
\hline \multirow{2}{*}{$\begin{array}{l}\text { After } \\
\text { wash }\end{array}$} & Pig fattener & $5.27 \times 10^{11 \mathrm{~B}} \pm 1.07$ & $5.22 \times 10^{11 \mathrm{~B}} \pm 1.06$ & $5.2 \times 10^{11 C} \pm 1.11$ \\
\hline & Farrowing & $6.1 \times 10^{11 \mathrm{Bb}} \pm 1.07$ & $6.82 \times 10^{11 \mathrm{Bb}} \pm 1.23$ & $2.39 \times 10^{11} \pm 1.10^{\mathrm{Ba}}$ \\
\hline \multirow{2}{*}{$1 \mathrm{hr}$ PD } & Pig fattener & $3.84 \times 10^{11 \mathrm{Bb}} \pm 1.06$ & $4.64 \times 10^{11 \mathrm{Bb}} \pm 1.06$ & $2.06 \times 10^{11 \mathrm{Ba}} \pm 1.12$ \\
\hline & Farrowing & $4.86 \times 10^{11 \mathrm{ABb}} \pm 1.08$ & $5.39 \times 10^{11 \mathrm{Bb}} \pm 1.16$ & $1.77 \times 10^{11 \mathrm{Aa}} \pm 1.04$ \\
\hline \multirow{2}{*}{8 hr PD } & Pig fattener & $1.68 \times 10^{11 A a} \pm 1.12$ & $3.19 \times 10^{11 \mathrm{Ab}} \pm 1.10$ & $1.37 \times 10^{11 \mathrm{Aa}} \pm 1.16$ \\
\hline & Farrowing & $3.15 \times 10^{11 \mathrm{Ab}} \pm 1.07$ & $2.7 \times 10^{11 \mathrm{Ab}} \pm 1.16$ & $1.36 \times 10^{11 A a} \pm 1.14$ \\
\hline \multirow{2}{*}{$24 \mathrm{hr}$ PD } & Pig fattener & $9.51 \times 10^{11 C} \pm 1.09$ & $8.15 \times 10^{11} c_{ \pm 1.03}$ & $8.5 \times 10^{11 \mathrm{D}} \pm 1.02$ \\
\hline & Farrowing & $9.84 \times 10^{11 \mathrm{Cb}} \pm 1.06$ & $7.94 \times 10^{11 \mathrm{Bb}} \pm 1.11$ & $6.19 \times 10^{11 \mathrm{Ca}} \pm 1.06$ \\
\hline
\end{tabular}

PD: Post Disinfection, Means bearing different superscript in the same row and column differ significantly 
Divyalakshmi, D. et al. / J. Appl. \& Nat. Sci. 12(2): 79 - 83 (2020)

Table 6. Correlation between seasons and treatments on microbial load in pig fattener sty.

\begin{tabular}{llllll}
\hline Source & $\begin{array}{l}\text { Type III Sum of } \\
\text { Squares }\end{array}$ & d.f & Mean Square & F & Significance \\
\hline Corrected Model & $218.377^{\mathrm{a}}$ & 59 & 3.701 & 35.827 & 0 \\
Intercept & 258634.278 & 1 & 258634.278 & 2503474.548 & 0 \\
season & 17.597 & 2 & 8.798 & 85.165 & 0 \\
Treatment & 3.766 & 3 & 1.255 & 12.152 & 0 \\
Time & 156.725 & 4 & 39.181 & 379.259 & 0 \\
Season * Treatment & 6.734 & 6 & 1.122 & 10.864 & 0 \\
Season * Time & 4.375 & 8 & 0.547 & 5.293 & 0 \\
Treatment * Time & 12.864 & 12 & 1.072 & 10.377 & 0 \\
season * Treatment * Time & 16.316 & 24 & 0.68 & 6.58 & 0 \\
Error & 30.993 & 300 & 0.103 & & \\
Total & 258883.648 & 360 & & & \\
Corrected Total & 249.37 & 359 & & & \\
\hline
\end{tabular}

Table 7. Correlation between seasons and treatments on microbial load in farrowing pen.

\begin{tabular}{llllll}
\hline Source & Type III Sum of Squares & d.f & Mean Square & F & Sig. \\
\hline Corrected Model & $259.158^{\mathrm{a}}$ & 59 & 4.393 & 3.291 & 0 \\
Intercept & 260046.934 & 1 & 260046.934 & 194857.393 & 0 \\
Season & 53.158 & 2 & 26.579 & 19.916 & 0 \\
Treatment & 4.479 & 3 & 1.493 & 1.119 & 0.342 \\
Time & 159.405 & 4 & 39.851 & 29.861 & 0 \\
Season * Treatment & 8.572 & 6 & 1.429 & 1.071 & 0.38 \\
Season * Time & 9.477 & 8 & 1.185 & 0.888 & 0.527 \\
Treatment * Time & 11.344 & 12 & 0.945 & 0.708 & 0.743 \\
Season * Treatment * Time & 12.724 & 24 & 0.53 & 0.397 & 0.996 \\
Error & 400.365 & 300 & 1.335 & & \\
Total & 260706.456 & 360 & & & \\
Corrected Total & 659.523 & 359 & & & \\
\hline
\end{tabular}

2016, Gosling et al. 2018 and Jiang et al. 2018). When chlorine dioxide reacts and decays, chlorite and chlorate are formed both of these compounds have bactericidal effect (Volk, 2002). After the contact time, the bacterial load started to increase due to accelerated decomposition of chlorine dioxide, which could be anticipated to occur either hrough reductive reactions or photolysis.

Effect of sodium hypochlorite pig fattener sty and farrowing pen during different seasons are presented in Table 3 . It is noted that the efficacy of sodium hypochlorite in the floor of pig fattener sty was highly significant $(P<0.01)$ between seasons. It is evident that the action of sodium hypochlorite as a disinfectant did not differ significantly between seasons, whereas reduction in floor microbial load, post disinfection was highly significant $(P<0.01)$ during rainy and winter season. The antiseptic effect of sodium hypochlorite in the present study is in agreement with the findings of Aarnisalo et al. (2007) and Kaoud et al. (2013). The decreased bactericidal action of sodium hypochlorite in farm premises may be due to the inactivation of sodium hypochlorite by the presence of organic soiling and the instability of the compound in warm and sunny conditions as suggested by Fotheringham (1995).

Effect of calcium hypochlorite pig fattener sty and farrowing pen during different seasons are presented in Table 4, which depicts that season and post disinfection count significantly $(P<0.01)$ are influenced by the application of calcium hypochlorite on the floor in fattener pig sty. Action of bleaching powder is influenced by temperature, $\mathrm{p}^{\mathrm{H}}$, and presence of organic substance in floor of livestock premises (Linton, 1940). Since the water used for cleaning the sheds had nearly a neutral acidity, which may decrease the effect of bleaching powder.

Effect of cow urine based disinfectant in pig fattener sty and farrowing pen during different seasons are presented in Table 5. It is observed that there was a highly significant $(P<0.01)$ reduction in floor microbial load of pig fattener sty and farrowing pen in all the seasons by the application of cow urine based disinfectant. Cow's urine is an effective natural agent in inhibiting bacteria and fungi, and also has a high potential lipase activity (Kumar, 2013). Neem oil was found to contain different chemical substances viz., azadirachtin, meliantrol and salanin which were responsible for the pesticidal, larvicidal and insecticidal activities. The main constituent of cow urine that showed disinfectant activity was due to carbolic acid, which is a mixture of phenol and cresol (Mandavgane et al. 2005). The decreased activity of the cow urine based disinfectant used in the present study may be due to the decreased concentration of Ocimum tenuiflorum leaf extract used, since $500-600 \mathrm{mg} / \mathrm{l}$ of leaf extract with a contact time of 15-16 hours was required for inactivating E.coli and other harmful organisms as 
suggested by Sundaramurthi et al. (2012) and Kayastha (2014). In pig fattener sty the order of efficacy of disinfectants were chlorine dioxide > sodium hypochlorite $>$ cow urine based disinfectant $>$ calcium hypochlorite in all the seasons of the year, respectively. In farrowing pen the order of efficacy of disinfectants were chlorine dioxide > sodium hypochlorite $>$ calcium hypochlorite $>$ cow urine based disinfectant in all the seasons of the year, respectively. The seasonal effect of the disinfectants (Table 6 and 7) may be due to the influence of temperature, humidity (both absolute and relative), sunlight (ultraviolet light) exposure and even atmospheric pollutants. These factors will affect the various bacterial organisms in different ways and degrees, and it is sometimes difficult to make generalizations. Hence, it is concluded that spraying with chlorine dioxide reduced the floor microbial load significantly than other disinfectants used.

\section{Conclusion}

A study was conducted to assess and compare the disinfection efficacy. Chlorine dioxide, sodium hypochlorite, calcium hypochlorite and a cow urine based mixture were tested for their efficacy as disinfectant in swine farrowing and fattening facilities. The disinfectants were applied by recommended protocols. The efficacy was determined by dilution method. The study illustrated the order of disinfectants in decreasing order as follows chlorine dioxide > sodium hypochlorite > cow urine based disinfectant $>$ calcium hypochlorite in all the seasons of the year, respectively. In farrowing pen the order of efficacy of disinfectants were chlorine dioxide $>$ sodium hypochlorite $>$ calcium hypochlorite $>$ cow urine based disinfectant in all the seasons of the year, respectively.

\section{ACKNOWLEDGEMENTS}

The author is thankful to the Professor and Head, Livestock Farm Complex, Tamil Nadu Veterinary and Animal Sciences University, Chennai-51 for extending all facilities to carry out this work.

\section{REFERENCES}

1. Aarnisalo $\mathrm{K}$, Lunden $\mathrm{J}$, Korkeala $\mathrm{H}$ and Wirtanen G. (2007). Susceptibility of Listeria monocytogenes strains to disinfectants and chlorinated alkaline cleaners at cold temperatures. LWT- Food Science and Technology, 40(6): 1041-1048. https:// doi.org/10.1016/j.Iwt.2006.07.009

2. Fotheringham V J. (1995). Disinfection of stockyards. Rev. - Off. Int. Epizoot. 14(2):293- 307.

3. Gibson, H., J.H. Taylor, K.E. Hall and J.T. Holah, 1999. Effectiveness of cleaning techniques used in the food industry in terms of the removal of bacterial biofilms. J_Appl Microbiol. 87(1):41-48

4. Gosling, R. J. (2018). A review of cleaning and disinfection studies in farming environments. Livestock, 23 (5), 232-237.

5. Graslund, S. and Bengtsson, B.E. (2001) Chemicals and biological products used in south-east Asian shrimp farming, and their potential impact on the environment - a review. Sci Total Environ 280, 93131

6. Jiang, L., Li, M., Tang, J., Zhao, X., Zhang, J., Zhu, H., ... \& Zhang, X. (2018). Effect of different disinfectants on bacterial aerosol diversity in poultry houses. Front. Microbiol, 9, 2113.

7. Kaoud, H.A. (2013). Effect of disinfectants on highly pathogenic avian influenza virus (H5N1) in lab and poultry farms. IJESIT. 2(5): 144-149.

8. Kayastha B L. (2014). Queen of herbs tulsi (Ocimum sanctum) removes impurities from water and plays disinfectant role. J.Med.Plant.Res 2(2):18.

9. Kumar S. (2013). Analysis of cow's urine for detection of lipase activity and anti- microbial properties. Int.J.Sci.Biol.Sci. 7(1): 01-08. e-ISSN: 22783008, p-ISSN:2319-7676

10.Lewis, S. and Mclndoe, A.K. (2004) Cleaning, Disinfection and Sterilization of Equipment. Anaesth Intens Care Med 5, 360-363.

11.Luyckx, K. (2016). Evaluation and implication of cleaning and disinfection of broiler houses and pig nursery units (Doctoral dissertation, Ghent University).

12. Mandavgane S A, Rambhal A K and Mude N K. (2005). Development of cow urine based disinfectant. Natural Product Radiance. 4(5) 410-415.

13.Sundaramurthi $P$, Dhandapani $S$, Ponnusamy $S$ and Subbaiyan M. (2012). Effect of Tulsi (Ocimum Sanctum) as a Disinfectant for Water Treatment. Hitek Journal of Bio Sciences and Bioengineering. 1(1):1-7. ISSN: $2277-2197$

14. Thomas C K, Sastry N S R and Ravindran G. (2012). Dairy bovine production, $2^{\text {nd }}$ revised edn., Kalyani publishers, New Delhi. pp. 545-546.

15. Volk C J, Hofmann R, Chauret C, Gagnon G A, Ranger $G$ and Andrews R C. (2002). Implementation of chlorine dioxide disinfection: Effects of the treatment change on drinking water quality in a full-scale distribution system. Environ Eng 1(5): 323-330. https://doi.org/10.1139/s02-026 